\title{
The Closer Bridge towards Islamic Studies in Higher Education in Malaysia and Indonesia
}

\author{
Abd. Rachman Assegaf ${ }^{1}$, Abd. Razak Bin Zakaria², Abdul Muhsein Sulaiman² \\ ${ }^{1}$ State Islamic University (UIN) Sunan Kalijaga Yogyakarta, Yogyakarta, Indonesia \\ ${ }^{2}$ Faculty of Education, University of Malaya, Kuala Lumpur, Malaysia \\ Email: abdassegaf@yahoo.co.id, abdrazakzakaria@yahoo.com,muhsin.sulaiman@yahoo.com
}

Received June 25 $5^{\text {th }}$, 2012; revised July $28^{\text {th }}$, 2012; accepted August $14^{\text {th }}, 2012$

\begin{abstract}
The transformations of Islamic higher education in Indonesia have occurred since the establishment of STI to PTAIN, then IAIN and UIN. It has tremendous impact on the implementation of models of Islamic studies. At early stage of development, Islamic higher education in this country tends to follow a normative-idealistic approach of Islamic studies due to the huge influences of many Middle Eastern graduates. However, changes of Islamic studies approach come to exist when the Western graduates bring nonscriptualistic methodologies and multidisciplinary approach in Islamic studies. If compared to Malaysia, the two poles of Eastern or Western and Islamic or non-Islamic higher education types have been integrated with the paradigm of Islamization of knowledge. Recent development indicates that Malaysian and Indonesian universities have intensified their mutual cooperation through $U$ to $U$ or $G$ to $G$ Memorandum of Understanding. There are several ways of encounters, namely teacher (or lecturer) and student exchanges, literature line, bilateral cooperation, and informal factors. With the closer link between the two people of these countries, the bonds between Islamic studies connecting the two countries have become closer.
\end{abstract}

Keywords: Islamic Studies; Higher Education; Malaysia; Indonesia

\section{Introduction}

Debates on international linkage for Islamic studies have initiated the academic problems whether it will expand the ideology of transnational Islam or not. Most accusations are addressed to the Middle Eastern graduates who returned to their home country with rigid and normative-idealistic approach on practicing Islam, while western alumni are commonly branded as having a rational and non-scriptualistic approach. The influences of Eastern or Western outlook on Islam apparently happen in Islamic higher education in Malaysia and Indonesia. Tendencies towards integration of revealed knowledge and modern sciences have drawn much attention from Muslim scholars of both countries. Islamic studies in Malaysian universities which from inception decided to implement basic formulations of the World Islamic Conference held in Makkah in 1977, have internalized Islamization of knowledge. On the other hand, Islamic higher education in Indonesia takes a more moderate stand on Islamic studies which stand for non-dichotomy of knowledge while developing Islamic values in real life. The problems arose when Islamic studies in Malaysian and Indonesian universities have become an alternative model. This paper tries to elaborate further on the ways Islamic studies had become institutionalized in higher education in Malaysia and Indonesia and how the link between the two were built through encountering factors.

\section{Higher Education: Institutionalized Islamic Studies}

The rise of Islamic studies in higher education in Indonesia may not be separated from the development of STI (Sekolah
Tinggi Islam or Islamic College) that was built before Indonesia's Independence in 1945. From inception, some Muslim scholars in Masyumi gave the name for this higher education level as STI on 27 Rajab 1364 H or 8 July 1945. The inauguration ceremony was held in the Office Building of Immigration, Gondangdia, Jakarta. The first rector was Prof. K. H. A. Kahar Muzakkir (Djaelani, 1982) with M. Natsir as his secretary.

When the capital city of Jakarta was moved by the Government of Republic of Indonesia to Yogyakarta, the STI that was established not long before had to be moved also to Yogyakarta on 10 April 1946. Many Muslim leaders agreed to develop and extend the roles and functions of STI to university level. In November 1947 the committee was built to establish the Indonesia Islamic University (UII) with four faculties: Faculty of Religion, Faculty of Law, Faculty of Economics, and Faculty of Education (Departemen Agama, 2000).

In 1950, the Government enacted a Regulation on the establishment of those two Higher Education institutions, namely: State Higher Education for Islamic Studies (PTAIN) and Gadjah Mada University (UGM). PTAIN was basically formed by amalgamation of Faculty of Religion of UII based on State Regulation Num.034/14 August 1950 and Academy of Religious Science (Akademi DinasIlmu Agama or ADIA) based on Ministry of Religious Affairs Decree Num. 1 year 1957/1 January 1957 (Sumardi, 1976; Azra, 2011). Now, PTAIN consists of three types of institutions: UIN (State Islamic University), IAIN (State Institute of Islamic Studies), and STAIN (National College of Islam), and Higher Islamic Education run by private organizations such as NU and Muhammadiyah (PTAIS or Private Islamic Higher Education).

PTAI (Perguruan Tinggi Agama Islam or Islamic Higher 
Education) is the highest educational institution in Indonesia and is controlled by the Ministry of Religious Affairs. It has spread throughout the country and plays a decisive role as Santri's major choice of higher education. According to recent statistical data provided by the Ministry of Religious Affairs (MORA), Islamic Higher Education has 6 UINs, 13 IAINs, 33 STAIs, and 541 PTAISs. It could be summarized that PTAIS has strategic position and account for more than $80 \%$ of Islamic higher education (www.pendis.info, 2010). This huge transformation has led Islamic higher education to carry on their shoulders two fundamental tasks: the advancement of Muslim intellectual discourse and the betterment of Muslims' understanding of their religious practices. In other words, Islamic higher education has undertaken both academic roles, and so Islamic studies become institutionalized.

In the case of UIN Sunan Kalijaga Yogyakarta, current development indicates that this Islamic university is implementing a new paradigm of three pillars of Islamic studies: civilization of text (hadharah al-nash), civilization of science (hadharah al-'ilm), and civilization of philosophy and ethics (hadharah al-falsafahwa al-akhlaq). The complete faculties of UIN Yogyakarta are the following: the Faculty of Tarbiyah and Teaching Sciences; the Faculty of Syariah and Law; the Faculty of Ushuluddin and Social Changes; the Faculty of Adaband $\mathrm{Hu}-$ manities; the Faculty of Dakwa and Communication; the Faculty of Humanity and Social Sciences; and the Faculty of Science and Technology. Subject materials taught in this university consist of revealed knowledge such as Tafsir (Qur'anic Exegesis), Hadith (Prophetic Tradition), 'ilm al-Fiqh (Islamic Law and Jurisprudence), 'ilm al-Kalam (Islamic Theology), Dakwah (Islamic Propagation), Tarikh (History of Islamic Civilization), Arabic, besides modern knowledge such as sociology, philosophy, education, research methods, and so forth. What this university meant by civilization of text (hadlarah al-nash) is represented by revealed knowledge or classical Islamic studies, while modern sciences are used as basic materials for shaping the civilization of science (hadlarah al-'ilm) and civilization of philosophy and ethics (hadlarah al-falsafahwal al-akhlaq) (Abdullah, 2003). This paradigm is well-known as integrative and interconnectivity between religious sciences and modern or general sciences.

In running the university, this UIN has also three pillars: autonomy, accountability and quality assurance. Based on that paradigm, UIN Sunan Kalijaga Yogyakarta works hard to do many things:

1) Integration of epistemology of science to eradicate the existing dichotomy between modern sciences (al-ulum al-dunya) and religious sciences (al-ulum al-din).

2) To give moral foundation for developing science and technology (Iptek, ilmu pengetahuan dan teknologi) and enlighten faith and obedience (Imtaq, imandantaqwa), so that the two will run side by side.

3) To articulate Islamic teaching professionally into social life to bridge the gap between religious norms and social sophistication.

4) Developing research, either quantitative or qualitative, and contribute to enhancing the quality of life of the whole community through professional duties.

5) To give moral and spiritual foundation for national development and achieving optimum human recourses.

6) Increasing quality in all aspects of institutions, academic activities, managerial and physical improvements.
PTAI was established through the dedication of Middle Eastern graduates. The development of PTAI in Indonesia could not have been achieved without the devotional efforts of these graduates. At the time, the model for Islamic studies in IAIN was the tradition of universities in the Middle East, particularly Al-Azhar University (Assegaf, 2005), which put more emphasis on a normative-idealistic approach than on anything else (Azra, 2011). However, Islamic higher education in Indonesia, although formerly "institutionally al-Azharized" is not so today. PTAI have dualistic tendencies; some regard al-Azhar University as supreme and others regard al-Azhar as a strategic resource. During the Soeharto Regime, under the influence of existing policies and agenda, PTAI transformed its structure from being dogmatically oriented to adopting approaches towards western-oriented methodologies through the effort of western graduates. Consequently, PTAI today has a non-scriptualistic character; it features not only Islamic doctoral studies, such as theology, law, and Arabic, but also subjects integrated with a wide spectrum of learning, which can accommodate modern Indonesian society with a religion-oriented methodology (Ibid).

Along with the IAIN conversion into UIN, the emphasis on normative-idealistic style of Islamic studies which were promoted by Middle Eastern alumni merged cohesively with the renewal of western-oriented and non-scriptualistic character. It is evident now to find Arabic text books in libraries besides English references. The establishment of International Desk and mutual cooperation abroad in several UINs has broadened the spectrum of Islamic studies at the home university. Many international forums, such as seminars and conferences were held at the faculty and university level to strengthen ties between universities and countries. Recent MoU had been signed by Faculty of Tarbiyah and Teaching Sciences through university authorities with the Faculty of Education, University of Malaya (UM), Kuala Lumpur, Malaysia. It seems that the joint cooperation between universities had crossed the boundary of Eastern or Western countries, but also neighboring countries. The gate to closer ties towards Islamic studies at UIN and UM is opened.

\section{Islamic Studies in Indonesia}

Historically speaking, Islam came to the Indonesian archipelago long before European visitors had landed in Indonesia as early as the 14th century. Theories on the coming of Islam in Indonesia could be summarized into two strands: Gujarat theory which stated that Islam had been spread to Indonesia through the Southern part of India, by traders from Gujarat, since the 13th century (Mudzhar, 1993). However, this theory was silentin explaining the process of shaping Muslim communities in SamuderaPasai, better known as Aceh today. Before Islam was established amongst Indonesian communities, Muslim traders had been present for several centuries. Ricklefs (1995) identified two overlapping processes by which the Islamization of Indonesia occurred: Indonesians either came into contact with Islam or converted, and/or foreign Muslim Asians (Indians, Chinese, Arabs, etc.) settled in Indonesia and mixed with local communities. This leads to the second theory, Arab theory, which argued that Islam is thought to have been present in Indonesia as early as the Islamic era from the time of the third caliph of Islam, 'Uthman (644-656 A.D.) From the time, Islamic propagation, education and studies, had begun.

According to Mahmud Yunus (1992), Islam in Indonesia was 
spread through Islamic institutions such as surau (small Mosque), Mosque, pesantren (Islamic boarding school), madrasah (Islamic school), public school, and then developed in higher educational institutions (see also Steenbrink, 1994). In the surau and Mosque, Muslim students study the basic tenets of Islam by reciting and memorizing The Holy Qur'an from chapter 30 ( Juz 30) popularly known as turutan, to the entire verses of Qur'an (Yunus, 1992). While pesantren was the eldest Islamic educational institution, nationally rooted, and part of Islamic studies for Indonesian students. The Pesantren education system originated from traditional Javanese pondokan (dormitories) with the main aim to deepen knowledge of the Holy Qur'an, particularly through the study of Arabic, exegesis (tafsir), the Traditions of the Prophet (Hadith), Islamic law (fiqh), and theology ('ilmkalam) (See Dhofier, 1994). As social institutions, pesantren have played a major role over the centuries. They emphasise cores values of sincerity, simplicity, individual autonomy, solidarity and self-control. However, pesantren grew slowly after Dutch colonialisation in the archipelago.

After the establishment of public schools by the Dutch authority in Indonesia in the early 19th century, madrasahwere built and known as an alternative model of Islamic educational institution along with its counterparts since it offered an integrative approach to Islamic studies and modern sciences. Post-Independence Day in 1945, the Ministry of Religious Affairs of the Republic of Indonesia paid more attention to developing madrasah as formal Islamic schools with $30 \%$ of Islamic studies subjects and 70\% of modern sciences (Assegaf, 2005). If compared to public schools, Islamic studies included as obligatory subject matter which comprise of only two tracks or 80 minutes for every week class meeting for students of elementary to senior high school. Beside, in public school, Islamic studies are designed as broad-field subject matters combining all sub-subjects such as Arabic, exegesis (tafsir), the Traditions of the Prophet (Hadith), Islamic law (fiqh), theology ('ilmkalam), and Islamic history and civilization (tarikh). At this point, multiple problems arise both in madrasah and schools: on one hand for madrasah students they have to bear double burden with the heavy $30 \%$ weightage of Islamic studies, while on the other hand, school students were unable to comprehend Islamic studies except in the cognitive domain. These are amongst the reasons for $60 \%$ of the students of Islamic higher institutions coming from madrasah graduates.

Most of madrasah graduates preferred to continue their studies in Islamic universities because of their provision in Arabic and Islamic studies. Only small numbers, especially those with higher marks try to compete and enroll in public or national universities. Islamic studies higher education institutions in Indonesia are basically liberal institutes that prepare Muslim youths to work as teachers of not only Islamic instruction at madrasahs, pesantrens and public schools, but also of English, social and NGO activists, journalists, political activists, leaders of socio-religious organizations, as well as in the development of other Islamic institutions such as Islamic courts, Islamic banking and others (Azra, 2011). The culmination point of the transformation of Islamic higher education is the conversion of IAIN to UIN which took place formally since 2002. According to Azra, it should be clear that the conversion is not based on the idea of the "Islamization of knowledge", because it is to large extent questionable, since all knowledge and sciences are already Islamic. The conversion also shifts Islamic studies from the normative approach to the historical, socio- logical, and empirical approach. The normative approach tends to neglect human socio-historical realities and Muslims are often trapped into "spiritual satisfaction" which in turn distances Muslims from empirical situations. On the other hand, the historical and sociological approaches provide a wide range of analysis for the study of Islam, bringing social-historical realities into interaction with religious experience. The philosophical standpoint behind IAIN's conversion to UIN and changes towards the new paradigm of Islamic studies with the core idea of integrating normative approach with modern sciences has brought new orientation in curriculum, programs, administration, management and structure of knowledge.

However, after ten years of transformation, in spite of increased public interest towards Islamic studies in several UINs, the institution itself is seen as incapable to compete with already established national universities due to dualistic organization run by the Government. Islamic higher education is run by the Ministry of Religious Affairs, while public or national universities are under the Ministry of National Education. How will it be if the national universities open Islamic studies programs in their faculties and program studies, as happen in Malaysia?

\section{Malaysian Experience}

Since the Independence Day of Malaysia in 1957, Islamic studies were obliged to students and included in its curriculum with duration of 120 minutes per week. However, the Government does not impose Islamic education as an obligation for students to pass the examination; and as a consequence, the students pay little attention to Islamic studies. Until 1975, more steps were taken by the Department of Education to strengthen Islamic education. In 1982, Prime Minister Mahathir Mohammad decided to perform any policies to internalize Islamic values that caused more significant consideration amongst society as seen in the establishment of Islamic Bank, Islamic Assurance, International Islamic University, and so forth. A year after that policy, the Department of Education stated that moral values should be taught for non-Muslim students, while Islamic studies would be compulsory for Muslims (Balakrishnan, 2011).

In case of higher education, Islamic studies in Malaysian history were first introduced in the University of Malaya, Kuala Lumpur, with the formation of the Department of Islamic Studies in 1959. Prof. Dr. Muhammad Abdul Rauf, a renowned Islamic scholar from Egypt, was appointed as the first head of this department. Later, in 1981, this university has expanded its Islamic studies program from a departmental level into a fully fledged faculty known as the Academy of Islamic Studies (AkademiPengajian Islam) which until recent times comprises of the following faculties: Shari'ah, Usul al-Din, and Islamic Education (Muhd, 2011), Al-Qur'an and Hadith, Dakwah and Human Development, Islamic History and Civilization, SiyasahSyari'ah, and Applied Sciences with Islamic Studies (see website of Academy of Islamic Studies, UM, www.apium.um. edu.my and Buku Panduan Akademi Islam Universiti Malaya, 2006). The Academy offers B.A., M.A., and PhD programs for Islamic studies.

After that, the development of Islamic studies in Malaysian higher education could be seen through the establishment of faculties, departments, programs, and even university level. One of the well-known institutions is the Faculty of Islamic Studies at National University of Malaysia or Universiti Kebangsaan Malaysia (UKM) in Selangor. This faculty is made up 
of five departments, namely Usul al-Din, Philosophy, Syari'ah, Arabic Studies and Islamic Civilization, Qur'an and Sunnah Studies, Dakwah and Leadership Studies (see www.ukm.edu. my). This faculty had two principal objectives: to produce welltrained graduates with skills in Islamic studies, and to create a new generation whose understanding of Islam is sound and comprehensive, who have a healthy way of thinking, commitment, and sense of responsibility towards the nation and desire to create a disciplined society in line with the principles of Islam and its philosophy (Muhd, 2011). The UKM motto "Knowledge Leads" refers to the philosophy of integrating belief in Allah and beneficial knowledge. The idea to establish UKM had been initiated by Abdul KadirAdabi in 1920. Until the 1930s this idea was in discussion, and on 18 May 1970, this university was formally inaugurated. It has a number of faculties and departments, namely Faculty of Economy, Social Sciences and Humanities, Physics and Applied Sciences, Techniques, Medicine, Biology, Sciences, Education, Law, Computer, and Islamic Studies (Assegaf, 2003).

Another significant development in Islamic studies programs in Malaysia was the establishment of the International Islamic University of Malaysia (IIUM) or Universiti Islam Antarabangsa (UIA) at Gombak. The last mentioned university is quite similar with the State Islamic University (UIN) SunanKalijaga in which Islam is studied in a modern mode, besides having a different paradigm of integration of knowledge. IIUM actualized Islamic Revealed Knowledge and Human Sciences whereas from its establishment in 1983 Islamic studies became a core university subject; it is compulsory for all the students from various faculties to study fundamental subjects in Islam, such as: Qur'an, Hadith, Sirah, Islamic Theology, Shari'ah, and Akhlaq (see www.iium.edu.my). The entire subject was oriented towards the idea of the Islamization of knowledge, which means that revealed knowledge must become the principal guidance for human sciences subject. This idea of the Islamization of knowledge was also developed by a prominent figure Prof. Syed Muhammad Naquib Alattas in the Institute of Islamic Thought and Civilization better known as ISTAC which plays a creative role in the restoration of Islamic thought and civilization in its rightful place. The strong feature of ISTAC's academic curriculum is reflected in its ability to provide academics of high international reputation.

It is worth noting here that the establishment of IIUM was inspired by the First World Conference on Islamic Education in 1977 at Makkah. This university strives for moral and intellectual enforcement of Islamic society and for shaping Islamic values for all human behavior. IIUM has trained students in various disciplines and accepted representatives of 32 countries; $30 \%$ of its intake comprises international students. Various degree programs offered include: Doctor of Philosophy of Law, Master of Comparative Laws, Master of Arts in Islamic Revealed Knowledge and Heritage, Master of Education, Master in Library and Information Sciences, Master of Arts in Arabic, Master of Arts in English, and Master of Economics.

A summary of the Mission of IIUM consists of Integration of Islamic Revealed Knowledge and Human Sciences in a positive manner, Islamization of the ethics of Muslim academic and administrative staff of IIUM, to exemplify an international community of dedicated intellectuals, scholars, professionals, officers and workers who are motivated by the Islamic world-view and code of ethics as an integral part of their work culture, and comprehensive excellence (see www.iium.edu.my).
The above mentioned explanations show us that Islamic studies in Malaysia were enacted in various higher education, and not limited to what Indonesian usually called Islamic higher education (PTAI) and non-Islamic higher education (PerguruanTinggiUmum, PTU). In Malaysia, there is no separation between Islamic or non-Islamic higher education; both types of higher institutions offer Islamic studies as well as modern sciences.

\section{The Closer Bridge towards Islamic Studies of Both Countries}

Transnational linkage in Islamic studies of Indonesian students with Arab countries, primarily Makkah in Saudi Arabia and Al-Azharin Egypt had been established long before Indonesian independence in 1945. Indonesian Muslim scholars were connected with Makkah education through pilgrimage. Many prominent Indonesian figures who became religious leaders were graduated from this country after their long stay in Makkah. Prominent figures such as K. H. Ahmad Dahlan, the founder of Muhammadiyah, and K. H. Hasyim Asy’ari, the founder of Nahdhatul Ulama, were amongst the alumni of Makkah education. This period occurred until early 19th century before the canal Suez striving to Egypt was opened.

After the navigation line connecting towards Egypt through this canal were opened, the wave of transnational linkage for Indonesian students to Al-Azhar influxes rapidly along with the Governmental supports and the development of PTAI. The development of PTAI in Indonesia could not have been achieved without the devotional efforts of these graduates. Mahmud Yunus was one of the alumni of Al-Azhar University that contribute significantly to the establishment of the earliest model of Islamic higher education in Indonesia. According to statistical data from the Embassy of Indonesia in Cairo, the number of Indonesian students at Al-Azhar at the end of December 2009 was approximately 5,000 students, and the alumni have scattered into different Islamic educational institutions such as madrasah, pesantren, and PTAI.

However, Islamic higher education in Indonesia is "institutionally al-Azharized” but practically decreased nowadays. PTAI have dualistic tendencies; some regard al-Azhar University as supreme and others regard al-Azharas a strategic resource. The impact of Al-Azhar towards Islamic studies could be seen through the existing departments in PTAI which consist of the same faculties between the two, such as Faculty of Syari'ah (Islamic Law), Faculty of Ushuluddin (Islamic Theology), Faculty of Adab (Islamic Letters), and Faculty of Da'wah (Islamic Propagation). It is interesting to mention that structure of knowledge, curriculum, subject matters, text-books and literature of early model of PTAI was mostly similar with what we found in Al-Azhar at the time. Arabic literature written by Al-Azhar scholars were consumed as main references in the PTAI syllabuses, curriculum, and text-books.

In relation to the transmission of Arabic literature into PTAI, so many researches were conducted by PTAI lecturers and students on Islamic studies based on Arabic literature, both in classical as well as modern periods. In the classrooms, the process of teaching and learning held by the lectures often used Arabic literature as the main references. The university libraries also supported this process as shown by many collections of Arabic literature on Tafsir (Qur'anic exegesis), Hadith (the Prophet Traditions), Fiqh (Islamic Jurisprudence), Ilm al- 
Kalam (Islamic Theology), Adab (Islamic Letters), Tarikh (History of Islamic civilization), LughahArabiyah (Arabic language), DirasatIslamiyah (Islamic studies), and others. We also easily find translations from Arabic literature into Bahasa Indonesia in libraries and bookshops. Some publishers had preferred to translate Arabic literature for dissemination amongst the students of PTAI than selling the original Arabic texts. If compared to the huge number of PTAI institutions, lecturers and students, as above mentioned, we could conclude that Arabic literature have significant impact towards the mindset, thoughts, behavior, and movements of students and Islamic society in general. The Indonesian alumni of Al-Azhar and Arab universities in the Middle East have systematic networks and dominant roles in the development of PTAI in Indonesia.

However, along with the broader orientation of Islamic studies, with the instructions and programs of the Ministry of Religious Affairs of the Republic of Indonesia, since the 1970s numbers of PTAI's lecturers had been sent to study Islam not only to the Middle Eastern universities but also to the Western and the European universities such as Chicago University in USA, Leiden University in Netherlands, McGill University in Canada, Melbourne University in Australia, and so forth. On behalf of the Ministry of Religious Affairs, the Government had sent the PTAI lecturers to study Islam in many universities abroad since the mid-1970s to USA (UCLA, Columbia, Chicago and Harvard University), Canada (McGill University), Netherlands (Leiden University), Turkey (Ankara University) and Australia (Monashand Flinders University). While Middle Eastern universities consist of Saudi Arabia (Riyadh University) and Egypt (Al-Azhar University) (Effendi, 1998; Jabali, 2002; Sjadzali, 1993). Consequently, big changes had occurred in the development of PTAI orientation in Indonesia. In addition, their alumni had strategic position after their return from abroad to their home universities. During the Soeharto regime, under the influence of the policies and agenda, PTAI transformed its structure from being dogmatically oriented to adopting approaches towards western-oriented methodologies through the effort of western graduates. Consequently, PTAI today provides non-scriptualistic characters; it features not only Islamic doctoral studies, such as theology, law, and Arabic, but also subjects that are integrated with a wide spectrum of learning, which can accommodate modern Indonesian society with a religion-oriented methodology. At the same time, the Middle Eastern linkage and networks had loosened for several years until the Reform Era at the end of the 1990s under President Abdurahman Wahid, when the gateway to the Middle Eastern universities was intensified again.

Recent developments indicate that the transnational linkage in Islamic studies inclined to become closer to neighboring countries, especially Malaysia, while at the same time widening the roles of PTAI. By this mutual cooperation the local students could continue their studies in Malaysia as well as in their home country with the same acknowledgment of being graduated from international level universities. Geographically speaking, Malaysia and Indonesia are quite close neighboring countries that could be reached in a couple of hours by direct flight from many cities in both countries. The two countries also share land borders in Kalimantan facilitating connections between them. As the Indonesian Embassy stated, the Straits of Melaka link rather than divide people of the two countries (Kasim, 1987). Furthermore, along with the development of modern communication devices and transportation facilities, the distance be- tween the two countries had become even closer.

The collaboration in Islamic studies between both countries could be attributed to several factors. Firstly, teacher (or lecturer) and student factor. Since 2000, the number of Indonesian students in Malaysia has been increasing, and likewise the number of Malaysian students in Indonesia has also increased. In 2010, there were 13,627 Indonesian students in Malaysia out of Indonesia's 240 million populations, while 6086 Malaysian students were in Indonesia out of Malaysia's 28.5 million populations (www.kbrikualalumpu.org). Most Indonesian students registered in Malaysian universities by their own intention after they were rejected in national leading universities. Several students admitted that their choices here are due to ease of administration and lower cost if compared to Indonesian universities. However, they felt hardships to pass and graduate after entrance, and many take much longer time to accomplish their studies. Most Indonesian graduates lacked good command of English and have no prominent abilities whenever they come back to home universities. Indonesian university authorities generally preferred Western or European alumni to be entrusted with positions, rather than Malaysian university graduates, because of their productivity in scientific publications.

Problems faced by Indonesian students varied according to various factors. The accommodation system in KL with apartments, flats, and condominiums not only entail higher expenses for Indonesian students but also caused social segregation and individualism not prevalent in the home country. Typically, Indonesians were popular by their smile when they meet each other in spite of that being their first meeting (Errington, 1999); this is something that may not occur in KL lifestyles. It commonly happen, leaflets were put up at bus stops or somewhere, for room or house to let or rent with special conditions such as female only, Chinese only, Malays only, etc., with deposit twice higher than monthly fees plus facilities.

However, exchange programs have led to increasing number of Indonesian students and lecturers in Malaysia. At the end of 2011, there were 4000 Indonesian lecturers invited by Malaysian higher education institutes as visiting lecturers or senior research fellows (www.kbrikualalumpur.org). Many successful Indonesian students in Malaysia were appointed as lecturers or even offered as Permanent Resident (PR), and henceforth become leading figures and occupy strategic positions in Malaysian universities. It seems that the authorities were looking for talented Indonesian students to be appointed and listed as qualified human resources.

Concerning Islamic studies, several Malaysian universities have invited Indonesian scholars to become research fellows, visiting lecturers or external examiners. The number is growing much bigger in line with the intensifying joint-cooperation at the University to University level. The interest to study Islam in Malaysian universities is usually coming from Master or $\mathrm{PhD}$ students, especially when they received fellowship from the home university or on duty. Some can even afford to pay the whole cost of study by themselves. The relations between students and lecturers are fair whereas Malaysian lecturers have more time to supervise and assist in academic development of the students. In addition, there are no difficulties in language because of the similarities in culture of both countries.

Secondly, literature line is a factor in Malaysian-Indonesian cooperation. An interesting phenomenon could be cited here that many Islamic publications from Indonesian writers, mainly books, are able to be found easily in libraries or campus book- 
shops in Malaysia. The books written by a prominent scholar Buya HAMKA were the most popular Islamic readings in many campuses. We could find the books in bookstores and book exhibitions. Even in TV channel broadcasts of Islamic teachings by local Islamic scholars (ulama) they sometimes refer to Buya HAMKA's opinions on specific problems. Tafsir AlAzhar and Tasawuf Modern were amongst the benchmark literature for university students that were assumed to be the main references. Likewise, Tafsir al-Mishbahby the contemporary Indonesian expert on Qur'anic exegesis, Prof. QuraishShihab, also entered campus libraries and bookshops. In occasions such as international book fairs, many Indonesian publishers come to participate and contribute their publications. E-books and e-journals facilitated by the university authority also opened the gate for easier access for searching Islamic software. In short, the influx of Islamic literature could fill in the gap between the two countries. Suraus and mosques were among the public religious gatherings as well as places of worship used to transmit the Islamic teachings and movements (Nagata, 1984)

Thirdly, formal joint-cooperation through sponsorship of the Government or university which intensified nowadays has attracted many lecturers and students to involve in programs agreed upon. To name some, agreements to organize jointseminars, workshops or conferences between Universiti Malaya (UM), Universiti Kebangsaan Malaysia (UKM), Universiti Pendidikan Sultan Idris (UPSI), Universitas Islam Negeri (UIN), Universitas Indonesia (UI), Universitas Pendidikan Indonesia (UPI), Universitas Negeri Yogyakarta (UNY), and so forth have intensified academic linkages. The demand for mutual cooperation between higher education institutions had become unavoidable for developing universities with global perspectives. One of the realizations of joint-cooperation between the two universities is the establishment of a research team of the economic faculty of the Indonesian State University of Yogyakarta and Malaysian Sultan Idris University of Education (UPSI) which conducted a joint research on entrepreneurship education in vocational high schools. The research is a comparative study of entrepreneurship learning model in Indonesian and Malaysian vocational schools. It is carried out by monitoring the education system's curriculum, evaluation system and tradition among the education units of the two countries (Antaranews.com). With State Islamic University (UIN) Sunan Kalijaga, Faculty of Education University of Malaya has conducted a series of joint seminars on education since last year. The first seminar was conducted at UIN under the theme: Global Education Based on Local Wisdom, a pathway to promote further cooperation and a hallmark of better understanding between the two universities.

Besides university level collaboration, a regional effort to expand knowledge of teachers and educators in Southeast Asia has already begun with the establishment of SEAMO Center for Excellence in Indonesia and Malaysia. Specifically, the series of workshops aimed at sharing experiences in the endeavor to set up new SEAMEO centers and establishing closer relationship and networking between Indonesia and Malaysia. President Susilo Bambang Yudhoyono and Malaysian Prime Minister, Najib Razak agreed to increase the two countries' cooperation in the spirit of common welfare and progress.

\section{Concluding Remarks}

Malaysia and Indonesia are among the Islamic countries that have majority Muslim population in the world. The issues of religion are sensitive and need to be taken care of or handled wisely. People from both countries see the significant roles of Islam in their lives and social interactions. Institutions from the basic school to university level always play a pivotal role towards developing Islamic studies. In this context, the advancement of Islamic studies in higher education may be considered as the increasing influence of Islamic society. Malaysia and Indonesia have similar outlook towards developing Islamic studies but different approaches and nuances, whereas Malaysian universities have already narrowed the distinctive borders between Islamic and non-Islamic higher education, and have been promoting Islamization of knowledge. Indonesian universities are facing the dichotomist point of view in dealing with Islamic and non-Islamic higher education, and also institutionalized Islamic studies which are autonomously run by the Ministry of Religious Affairs. However, facilitative factors that lead Indonesian students to come to Malaysian universities and vice versa, in the long run, will fill in the gap and the bond between both countries, especially in Islamic education, will become closer.

\section{REFERENCES}

Abdullah, A. R. H. (1997). Pemikiran Islam di Malaysia: Sejarah dan aliran. Jakarta: Gema Insani Press.

Abdullah, A. (2003). Etika Tauhidik sebagaidasarkesatuanepistemologukeilmuan agama danumum: Dari paradigma Positivistik-Sekularistikkearah Teoantroposentrik-Integralistik. In Menyatukan kembali ilmu-ilmu agama dan umum: Upaya mempertemukan epistemologi Islam dan umum. Yogyakarta: Suka Press.

Assegaf, A. R. (2003). Internasionalisasi pendidikan: Sketsa perbandingan pendidikan di negara-negara Islam dan Barat. Yogyakarta: Gama Media.

Assegaf, A. R. (2005). Politik pendidikannasional: Pergeseran kebijakan pendidikan agama Islam dari pra-proklamasi ke reformasi. Yogyakarta: Kurnia Kalam.

Azra, A. (2011). From IAIN to UIN: Islamic studies in Indonesia. In K. Bustaman-Ahmad, \& P. Jory (Eds.), Islamic studies and Islamic education in contemporary Southeast Asia. Kuala Lumpur: Yayasan Ilmuwan.

Baharuddin, S. A., \& Aziz, A. (2011). Colonial knowledge and the reshaping of Islam, the Muslim and Islamic education in Malaysia. In K. B. Ahmad (Ed.), Islamic studies and Islamic education in contemporary Southeast Asia. Kuala Lumpur: Yayasan Ilmuwan.

Balakrishnan, V. (2011). Real-life dilemmas in moral education. Kuala Lumpur: University of Malaya Press.

Baqir, Z., \& Abdullah, I. (2011). The development and the role of religious studies: Some Indonesian reflections. In K. B. Ahmad (Ed.), Islamic studies and Islamic education in contemporary Southeast Asia. Kuala Lumpur: Yayasan Ilmuwan.

Departemen Agama (2000). Buku panduan IAIN Sunan Kalijaga. Yogyakarta: Proyek Pembinaan Perguruan Tinggi Agama IAIN Sunan Kalijaga.

Departemen Pendidikandan Kebudayaan (1998). Mengenal Pendidikan Tinggi di Indonesia. Jakarta: Pusat Informatika BadanStudi Komparatifdan Pengembangan Pendidikandan Kebudayaan.

Djaelani, A. T. (1982). Kebijaksanaan pembinaan kelembagaan agama Islam. Jakarta: Direktorat Jenderal Pembinaan Kelembagaan Agama Islam.

Dhofier, Z. (1994). Tradisi pesantren dan sejenisnya: Studi tentang pandangan hidup kiai. Jakarta: LP3ES.

Effendi, B. (1998). Munawir Sjadali: Pencairanketeganganideologis. In A. Azra (Ed.), Menteri-menteri agama RI: Biografi sosial-politik. Jakarta: INIS.

Errington, J. (1999). Language, religion, and identity in Indonesia. ISIM (International Institute for the Study of Islam in the Modern World) 


\section{A. R. ASSEGAF ET AL.}

Newsletter, 3, 16

Hashim, O. M. (1991). Pengisian misi pendidikan. Kuala Lumpur: Dewan Bahasadan Pustaka.

Jamhari, F. J. (2002). IAIN \& modernisasi Islam di Indonesia. Jakarta: Logos Wacana Ilmu.

Kasim, A. (1987). The unwelcome guest: Indonesian immigrants and Malaysian public responses. Journal of Southeast Asian Studies, 25, 265-278.

Mudzhar, M. A. (1993). Fatwa majelis ulama Indonesia: Sebuah studi tentang pemikiran hukum Islam di Indonesia, 1975-1988. Jakarta: INIS.

Muhd, N. M. (2011). Islamic studies programs in Malaysia's higher learning institutions: Responses to contemporary challenges of modernity, globalization and post 9/11. In K. Bustaman-Ahmad, \& P. Jory (Eds.), Islamic studies and Islamic education in contemporary Southeast Asia. Kuala Lumpur: Yayasan Ilmuwan.

Muhammad Zin, A. (1992). Akhlak Islam dalamkehidupanmasyarakat Muslim di Malaysia kini: Permasalahandancabaran. In Makalah seminar internasional tentang agama dan perkembangan kontemporer (suatu pembahasan perbandingan). Yogyakarta: Fakultas Us- huluddin IAIN Sunan Kalijaga.

Nagata, J. (1984). The flowering of Malaysian Islam: Modern religious radicals and their roots. Vancouver, BC: University of British Columbia Press.

Ricklefs, M. C. (1995). Modern history Indonesia. In D. Hardjowidjono (Ed.), Sejarah Indonesia modern. Yogyakarta: Gadjah Mada University Press.

Sumardi, M. (1976). Bibliografi pendidikan Islam di Indonesia: 19451975. Jakarta: Lembaga Penelitian Ilmu Agama dan Kemasyarakatan Badan Penelitiandan Pengembangan Agama Departemen Agama.

Sjadzali, M. (1993). Islam: Realitasbarudanorientasimasadepanbangsa. Jakarta: UI Press.

Steenbrink, K. A. (1994). Pesantren, madrasah, sekolah: Pendidikan Islam dalamkurunmoderen. Jakarta: LP3ES.

Von der Mehden, F. R. (1987). Malaysia: Islam and multiethnic politics. In J. L. Esposito (Ed.), Islam in Asia: Religion, politics, \& society. New York: Oxford University Press.

Yunus, M. (1992). Sejarah pendidikan Islam di Indonesia (3rd ed.). Jakarta: Mutiara Sumber Widya. 